\title{
Thermal Aspects of Solar Air Collector
}

\author{
Ehsan Mohseni Languri ${ }^{1}$ and Davood Domairry Ganji ${ }^{2}$ \\ ${ }^{1}$ University of Wisconsin - Milwaukee \\ ${ }^{2}$ Noshirvani Technical University of Babol, \\ ${ }^{1}$ USA \\ ${ }^{2}$ Iran
}

\section{Introduction}

The amount of solar radiation striking the earth's surface not only depends on the season, but also depends on local weather conditions, location and orientation of the surface. The average value of this radiation is about $1000 w / m^{2}$ when the absorbing surface is perpendicular to the sun's rays and the sky is clear. There are several methods exist to absorb and use this free, clean, renewable and very long lasting source of energy [1]. The solar collectors are one of the devices which can absorb and transfer energy of the sun to a usable and/or storable form in many applications such as drying the agricultural, textile and marine products as well as the heating of building [2]. There is variety of designs for the solar thermal collectors depending on their applications. For example, parabolic trough solar air collector is widely used in solar power plants where solar heat energy is used to generate electricity [3].

Flat plate solar collectors are the most common types of solar collectors used in many applications such as solar hot water panels to provide hot water or as solar air heater for pre-heating the air in building heating or industrial HVAC systems. In the solar hot water panel, a sealed insulated box containing a black metal sheet, called absorber surface, with built-in pipes is located faced to the sun. Solar radiation heats up water inside pipes, causing it to circulate through the system by means of natural convection. Then, water is delivered to a storage tank located above the collector. Such passive solar water heating devices used widely in hotels and home especially in southern Europe.

Several models of thermal solar flat plate collector are available and generally all of them consist of four major parts:

1. A flat-plate absorber, which absorbs the solar energy

2. A transparent cover(s) that allows solar energy to pass through and reduces heat loss from the absorber

3. A heat-transport fluid (air or water) flowing through the collector (water flows through tubes) to remove heat from the absorber

4. And finally, a heat insulating backing.

The exergy of a system defined as the maximum possible useful work during a process that brings the system into equilibrium with a heat reservoir [3]. Exergy can be destroyed by irreversibility of a process. One of the powerful methods of optimizing complex thermo dynamical systems is to do an exergy analysis, which is called the second law analysis as 
well. In 1956, Rant [4] proposed the term exergy that was previously developed by Gibbs [5] in 1873. One can find the details of this concept in the thermodynamics literature [6-9]. Saravanan et al. [10] used the exergy tool to analyze the performance of cooling tower. Bejan was the first person who developed and published the governing equations of exergy to solar collectors [11, 12]. Later Londono-Hurtado and Rivera-Alvarez [13] developed a model to study the behavior of volumetric absorption solar collectors and its performance. Their model is used to run a thermodynamic optimization of volumetric absorption solar collectors to maximize the energy output of heat extracted from the collector. Luminosu and Fara [14] used the thermodynamically analysis using exergy method to find out the best flow rate of the test fluid in their experiments.

Altfeld et al. $[15,16]$ claimed that the heat transfer characteristics of the absorber are less important in case of considering a highly insulated solar air heater. Torres-Reyes et al. [17] carried out energy and exergy analysis to determine the optimal performance parameters and to design a solar thermal energy conversion system. Kurtbas and Durmuş [18] analyzed several different absorber plates for solar air heater and found that there was a reverse relationship between dimensionless exergy loss and heat transfer, as well as pressure loss.

\section{Mathematical modeling}

In this section, a review has been done on the theoretical modeling of several different designs of solar air heaters. Theoretical modeling of a single cover solar air collector is derived comprehensively in this section. In this case, a single air flow between absorber and glass plates assumed to convey the heat of the solar radiation, Fig.1.

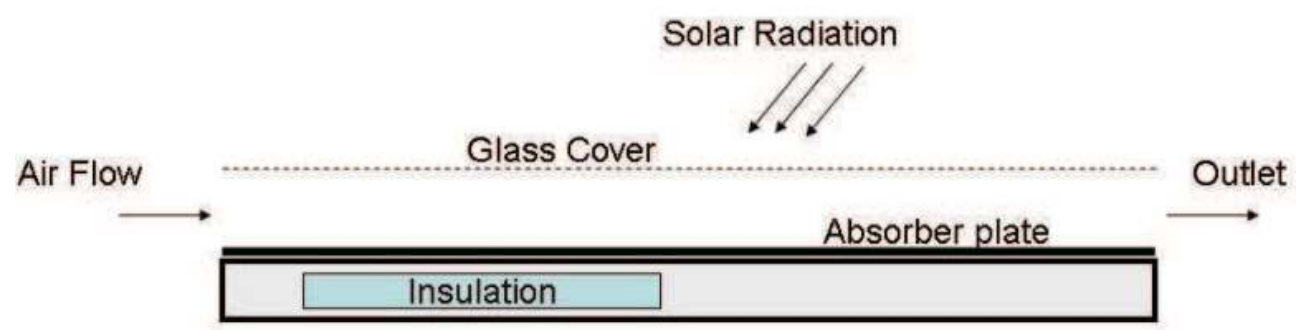

Fig. 1. Schematic view of single air flow solar air heater

The energy balance equations for cover glass, absorber plate and air flow respectively, are as following:

$$
\begin{gathered}
\alpha_{g} S=M_{g} C_{g} \frac{\partial T_{g}}{\partial t}+k_{g} \delta_{g} \frac{\partial^{2} T_{g}}{\partial x^{2}}+h_{w}\left(T_{g}-T_{a}\right)+h_{r g s}\left(T_{g}-T_{s}\right)+h_{c g f}\left(T_{g}-T_{f}\right)+h_{r p g}\left(T_{g}-T_{p}\right) \\
\alpha_{p} \tau_{p} S=M_{p} C_{p} \frac{\partial T_{p}}{\partial t}+k_{p} \delta_{p} \frac{\partial^{2} T_{p}}{\partial x^{2}}+h_{c p f}\left(T_{p}-T_{f}\right)+h_{r p g}\left(T_{p}-T_{g}\right)+U_{r}\left(T_{p}-T_{a}\right) \\
M_{f} C_{f} \frac{\partial T_{f}}{\partial t}+\frac{G_{f} C_{f}}{W} \frac{\partial^{2} T_{f}}{\partial x^{2}}=h_{c g f}\left(T_{f}-T_{g}\right)+h_{c p f}\left(T_{p}-T_{f}\right)
\end{gathered}
$$


One may assume following boundary and initial conditions for the given geometry:

$$
\begin{gathered}
T_{f}(t=0)=T_{p}(t=0)=T_{g}(t=0)=T_{a}(t=0) \\
\left.\frac{\partial T_{g}}{\partial x}\right|_{x=0}=0,\left.\quad \frac{\partial T_{g}}{\partial x}\right|_{x=L}=0,\left.\quad \frac{\partial T_{p}}{\partial x}\right|_{x=0}=0,\left.\quad \frac{\partial T_{p}}{\partial x}\right|_{x=L}=0
\end{gathered}
$$

\section{Back pass solar air heater}

Choudhury and Garg [19], Ong[20], Hegazy[21], Al-Kamil and Al-Ghareeb[22] investigated the heat transfer in the back pass solar air collectors. In such solar collectors, the absorber plate is placed behind the glass cover with a gap filled with static air from the glass cover. The flow of air is happens between the bottom surface of the absorber and the top surface of insulated surface, Figure 2.

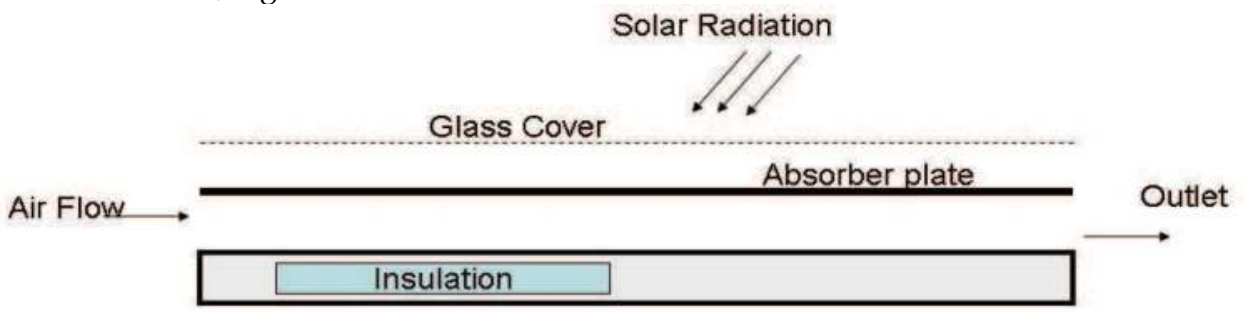

Fig. 2. Schematic view of back pass solar air heater

Garg et al. [23] developed the following mathematical modeling for the glass cover, absorber plate, air flow and the bottom plate, respectively as:

$$
\begin{gathered}
h_{g s}\left(T_{s}-T_{g}\right)+h_{r p g}\left(T_{p}-T_{g}\right)=U_{t}\left(T_{g}-T_{a}\right) \\
(\alpha \tau) S=h_{c p f}\left(T_{p}-T_{f m}\right)+h_{r p s}\left(T_{p}-T_{a}\right)+h_{r p b}\left(T_{p}-T_{b}\right)+h_{r p g}\left(T_{p}-T_{g}\right) \\
h_{c p f}\left(T_{p}-T_{f m}\right)=h_{c b f}\left(T_{f m}-T_{b}\right)+m C_{a}\left(T_{f o}-T_{a}\right) \\
h_{r p b}\left(T_{p}-T_{b}\right)=h_{c b f}\left(T_{b}-T_{f m}\right)+U_{b}\left(T_{b}-T_{a}\right)
\end{gathered}
$$

\section{Parallel pass solar air heater}

The design of the parallel pass solar air heater is to optimize the heat transfer transportation in the solar air heaters. This design consists of a glass cover, absorber plate and bottom insulated plate. There are two air flow channels which one is located between the glass cover and absorber and another one is located between the absorber and the bottom insulated plate, Figure 3.

Jha et al. [24] obtained the energy transport equations for the glass cover, channel 1, absorber plate, channel 2 and finally, bottom insulated plate as following

$$
M_{g} C_{g} \frac{\partial T_{g}}{\partial t}=\alpha_{g} S+h_{r p g}\left(T_{p}-T_{g}\right)+h_{c f 1 g}\left(T_{f 1}-T_{g}\right)-h_{c g w}\left(T_{g}-T_{w}\right)-h_{r g a}\left(T_{g}-T_{a}\right)
$$




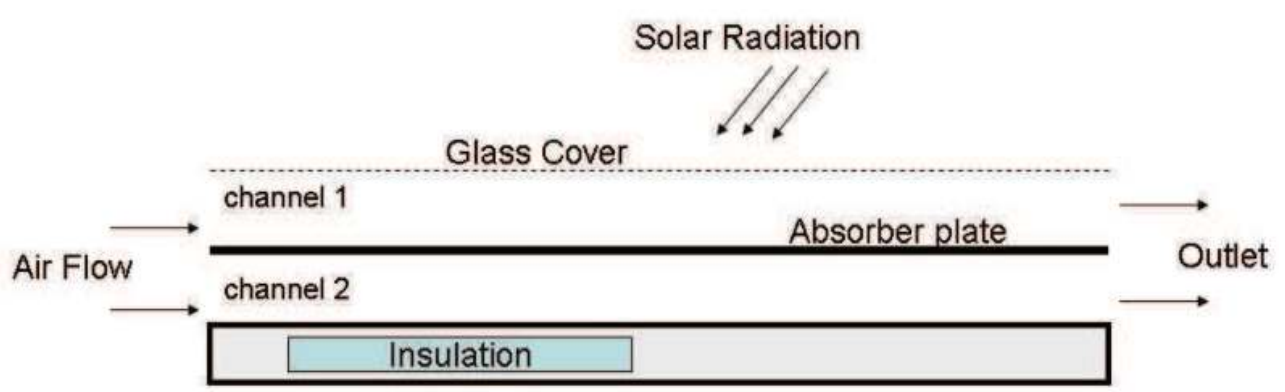

Fig. 3. Schematic view of parallel pass solar air heater

$$
\begin{gathered}
M_{f 1} C_{f} \frac{\partial T_{f 1}}{\partial t}=\frac{-G_{1} C_{f}}{W} \frac{\partial T_{f 1}}{\partial x}+h_{c p f 1}\left(T_{p}-T_{f 1}\right)-h_{c f 1 g}\left(T_{f 1}-T_{g}\right) \\
M_{1} C_{p} \frac{\partial T_{p}}{\partial t}=\alpha_{p} \tau_{g} S-k_{p} \delta_{p} \frac{\partial^{2} T_{p}}{\partial x^{2}}-h_{r p g}\left(T_{p}-T_{g}\right)-h_{c p f 2}\left(T_{p}-T_{f 2}\right)-h_{r p b}\left(T_{p}-T_{b}\right)-h_{c p f 1}\left(T_{p}-T_{f 1}\right) \\
M_{f 2} C_{f} \frac{\partial T_{f 2}}{\partial t}=\frac{-G_{2} C_{f}}{W} \frac{\partial T_{f 2}}{\partial x}+h_{c p f 2}\left(T_{p}-T_{f 2}\right)-h_{c b f 2}\left(T_{b}-T_{f 2}\right) \\
M_{b} C_{b} \frac{\partial T_{b}}{\partial t}=-k_{b} \delta_{b} \frac{\partial^{2} T_{b}}{\partial t}+h_{r p b}\left(T_{p}-T_{b}\right)-h_{c b f 2}\left(T_{b}-T_{f 2}\right)-h_{b}\left(T_{b}-T_{r}\right)
\end{gathered}
$$

Along with following boundary and initial conditions

$$
\begin{gathered}
\left.\frac{\partial T_{p}}{\partial x}\right|_{x=0}=0,\left.\frac{\partial T_{p}}{\partial x}\right|_{x=L}=0,\left.\frac{\partial T_{b}}{\partial x}\right|_{x=L}=0 \\
T_{f 1}(x=0)=T_{f i}, \quad T_{f 2}(x=0)=T_{f i}
\end{gathered}
$$

\section{Double-pass solar air heater}

Ho et al. [25] developed the mathematical modeling for the double pass solar air heater. In such solar collectors, the air is allowed to move faster than the simple collectors. In his mathematical modeling, following assumptions are considered:

- Temperatures of absorbing plate, bottom insulated plate and the fluid are only functions of air flow direction

- Glass cover and absorber plate do not absorb radiant energy

- The radiant energy absorbed by the outlet cover is negligible

Considering above assumptions, energy equations of cover 1 , absorber plate, bottom plate, channels $a$ and $b$ are as following, respectively:

$$
h_{r p g 2}\left(T_{p}-T_{g 1}\right)+h_{1}^{\prime}\left(T_{b}(z)-T_{g 1}\right)=U_{g 1 s}\left(T_{g 1}-T_{s}\right)
$$




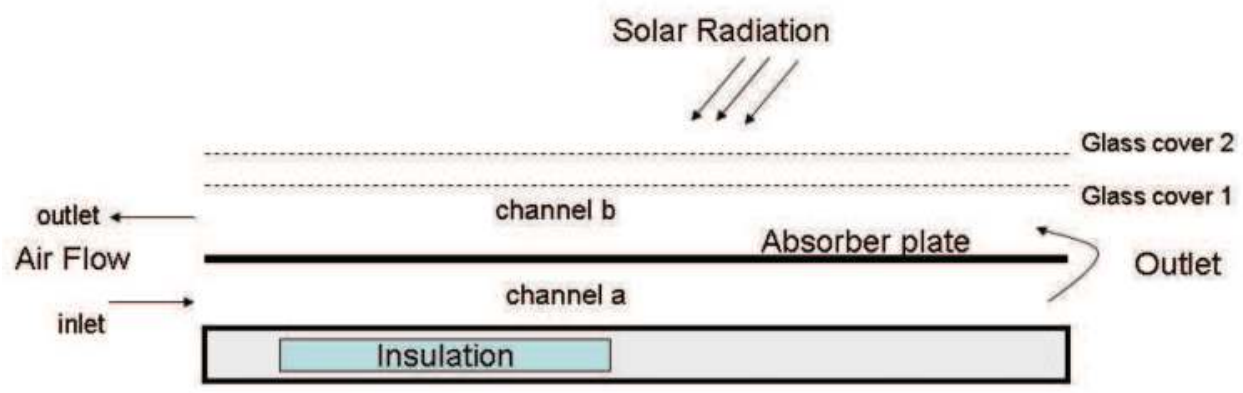

Fig. 4. Schematic view of double- pass solar air heater

$$
\begin{gathered}
\alpha_{p} \tau_{g 1} \tau_{g 2} S-h_{T}\left(T_{p}-T_{s}\right)+h_{B}\left(T_{p}-T_{s}\right)+h_{1}\left(T_{p}-T_{b}(x)\right)+h_{2}\left(T_{p}-T_{a}(x)\right) \\
h_{r p R}\left(T_{p}-T_{R}\right)+h_{2}^{\prime}\left(T_{a}(x)-T_{R}\right)=U_{B 1 s}\left(T_{p}-T_{s}\right) \\
h_{2}\left(T_{p}-T_{a}(x)\right)-h_{2}^{\prime}\left(T_{a}(x)-T_{R}\right)=\left[\frac{(R+1) m C_{p}}{W}\right] \frac{d T_{a}(x)}{d x} \\
h_{1}\left(T_{p}-T_{b}(x)\right)-h_{1}^{\prime}\left(T_{b}(x)-T_{g 1}\right)=\left[-\frac{(R+1) m C_{p}}{W}\right] \frac{d T_{b}(x)}{d x}
\end{gathered}
$$

\section{Energy analysis}

According to Duffie and Beckman [26], the rate of heat received by the air from the collector is

$$
\dot{Q}_{f}=\dot{m}_{f} C_{p}\left(T_{o}-T_{i}\right)
$$

One can find the specific collector power by dividing of the heat by the area of the collector [26]

$$
\dot{q}_{f}=\dot{Q}_{f} / A_{c o l}=\dot{m}_{f} C_{p}\left(T_{o}-T_{i}\right) / A_{c o l}
$$

The average daily useful heat per unit area of the collector can be obtained by adding up all radiation times as

$$
q_{a, d}=3600 \sum_{i=1}^{8} \dot{q}_{a, h o u r l y}
$$

in which $\dot{q}_{a, h o u r l y}$ is the useful heat per unit area of the collector for the hour $i$ of the test day. The energy efficiency of solar energy can be obtained by the ratio of absorbed energy to the total energy of the sun [14].

$$
\eta_{e n}=\dot{q}_{f} / G_{c o l}
$$

where $G_{c}$ is the solar radiation captured by the collector in $w / m^{2}$ 


\section{Exergy analysis}

According to Bejan et al. [11] and Bejan [12], there are two main sources of entropy generation in a solar air collector, one due to the friction of passing fluid, and the other one due to the thermal heat transfer or temperature change of air. Esens's [22] considered following assumptions to derive the exergy balance equations:

1. The process is steady state and steady flow.

2. The potential and kinetic energies are negligible.

3. Air is an ideal gas, so its specific heat is constant.

4. The humidity of air is negligible.

The general exergy balance for a steady state and steady flow process is

$$
\dot{I}=\dot{E} x_{\text {heat }}-\dot{E} x_{\text {work }}+\dot{E} x_{i}-\dot{E} x_{o}
$$

Considering above assumptions, following relations are defined for the mentioned terms:

$$
\begin{gathered}
\dot{E} x_{\text {heat }}=\sum\left(1-\frac{T_{0}}{T_{s}}\right) \dot{Q}_{s} \\
\dot{E} x_{\text {work }}=0 \\
\dot{E} x_{i}=\sum \dot{m}_{\text {in }}\left[\left(h_{\text {in }}-h_{0}\right)-T_{0}\left(s_{\text {in }}-s_{0}\right)\right] \\
\dot{E} x_{o}=\sum \dot{m}_{\text {out }}\left[\left(h_{\text {out }}-h_{0}\right)-T_{0}\left(s_{\text {out }}-s_{0}\right)\right]
\end{gathered}
$$

$\mathrm{Eq}$ (28) comes from the fact that there is no work has done during the process. From mass balance we have

$$
\sum \dot{m}_{i}=\sum \dot{m}_{o}=\dot{m}_{a}
$$

Upon substitution of Eqs (27) to (31) in Eq (26), one can find the rate of irreversibility as

$$
\dot{I}=\left(1-\frac{T_{a}}{T_{s}}\right) \dot{Q}_{s}-\dot{m}_{f}\left[\left(h_{o}-h_{i}\right)-T_{a}\left(s_{o}-s_{i}\right)\right]
$$

$\dot{Q}_{s}$ is the total rate of the exergy received by the collector absorber area from the solar radiation and is evaluated by this relation

$$
\dot{Q}_{s}=G_{c} \cdot A_{c o l} \cdot \tau \alpha
$$

where $\tau \alpha$ is absorbance-transmittance product of the covering glass and the absorber plate. The changes in enthalpy and entropy of test liquid, air, in the collector can be obtained using following two expressions:

$$
\begin{gathered}
h_{o}-h_{i}=C_{p}\left(T_{o}-T_{i}\right) \\
s_{o}-s_{i}=C_{p} \ln \left(\frac{T_{o}}{T_{i}}\right)-R \ln \left(\frac{P_{o}}{P_{i}}\right)
\end{gathered}
$$


One can find the final form of irreversibility expression by substituting Eqs (33) to (35) in Eq (32) as

$$
\dot{I}=\left(1-\frac{T_{a}}{T_{s}}\right) G_{c o l} \cdot A_{c o l} \cdot \tau \alpha-\dot{m}_{f} C_{p}\left(T_{o}-T_{i}\right)+\dot{m}_{f} T_{a} C_{p} \ln \left(\frac{T_{o}}{T_{i}}\right)-\dot{m}_{f} T_{a} R \ln \left(\frac{P_{o}}{P_{i}}\right)
$$

$T_{S}$ is apparent temperature of sun surface, which considered to be $6000 \mathrm{~K}$. In this equation the first term comes from the entropy generated due to heat transfer; second and third terms are related to the temperature change of air and last term is related to the entropy generated due to the friction of fluid. By definition, irreversibility is the total entropy generated times the ambient temperature [8]

$$
\dot{I}=\dot{S}_{g e n} T_{a}
$$

Therefore, the total entropy generated during the process will be

$$
\dot{S}_{g e n}=\frac{1}{T_{a}}\left[\left(1-\frac{T_{a}}{T_{s}}\right) G_{c o l} \cdot A_{c o l} \cdot \tau \alpha-\dot{m}_{f} C_{p}\left(T_{o}-T_{i}\right)\right]+\dot{m}_{f} C_{p} \ln \left(\frac{T_{o}}{T_{i}}\right)-\dot{m}_{f} R \ln \left(\frac{P_{o}}{P_{i}}\right)
$$

According the second law of thermodynamics, the exergy efficiency defined as [17]

$$
\eta_{\text {ex }}=1-\frac{\dot{I}}{\dot{E} x_{\text {heat }}}=1-\frac{\dot{S}_{g e n} T_{a}}{\left(1-T_{a} / T_{s}\right) \dot{Q}_{s}}
$$

\section{Error analysis}

There are two types of errors in doing the energy and exergy analysis;

One group comes from direct measurement, such as $\Delta G_{c}, \Delta T, \Delta P$ and $\Delta \dot{m}$

The second group of errors comes from indirect measurement, which are $\Delta \eta_{e n}$ and $\Delta \eta_{e x}$. Luminosu and Fara [14] proposed following relations for error analysis:

$$
\begin{gathered}
\Delta \eta_{e x}=\Delta \dot{I} / \dot{E} x_{\text {heat }}+\dot{I} \Delta \dot{E} x_{\text {heat }} / \dot{E} x_{\text {heat }}^{2} \\
\Delta \eta_{e n}=\Delta \dot{q}_{a} / G_{c}+\dot{q}_{f} \Delta G_{c o l} / G_{c o l}^{2}
\end{gathered}
$$

where each error term may be computed as following:

$$
\begin{gathered}
\Delta \dot{E} x_{\text {heat }}=\left(\Delta T / T_{s}+T_{a} \Delta T / T_{s}^{2}\right) A_{c o l}(\tau \alpha) G_{c o l}+\left(1-T_{a} / T_{s}\right) A_{c o l}(\tau \alpha) \Delta G_{c o l} \\
\Delta \dot{I}=T_{a} \Delta \dot{S}_{g e n}+\dot{S}_{g e n} \Delta T \\
\Delta \dot{S}_{g e n}=\left[R \ln \left(P_{o} / P_{i}\right)+C_{p} \ln \left(T_{i} / T_{o}\right)+C_{p}\left(T_{o}+T_{i}\right) / T_{a}\right] \Delta \dot{m}+G_{c o l} A_{c o l}(\tau \alpha) \Delta T / T_{a}^{2} \\
+\dot{m} C_{p}\left[1 / T_{o}+1 / T_{i}+2 / T_{a}+\left(T_{o}+T_{i}\right) / T_{a}^{2}\right] \Delta T+\dot{m} R\left[1 / P_{o}+1 / P_{i}\right] \Delta P \\
+A_{c o l}(\tau \alpha)\left[1 / T_{s}+1 / T_{a}\right] \Delta G_{c o l}
\end{gathered}
$$




$$
\Delta \dot{q}_{a}=C_{p}\left[\Delta \dot{m}\left(T_{o}+T_{i}\right)+2 \dot{m} \Delta T\right] / A_{c o l}
$$

\section{Nomenclature}

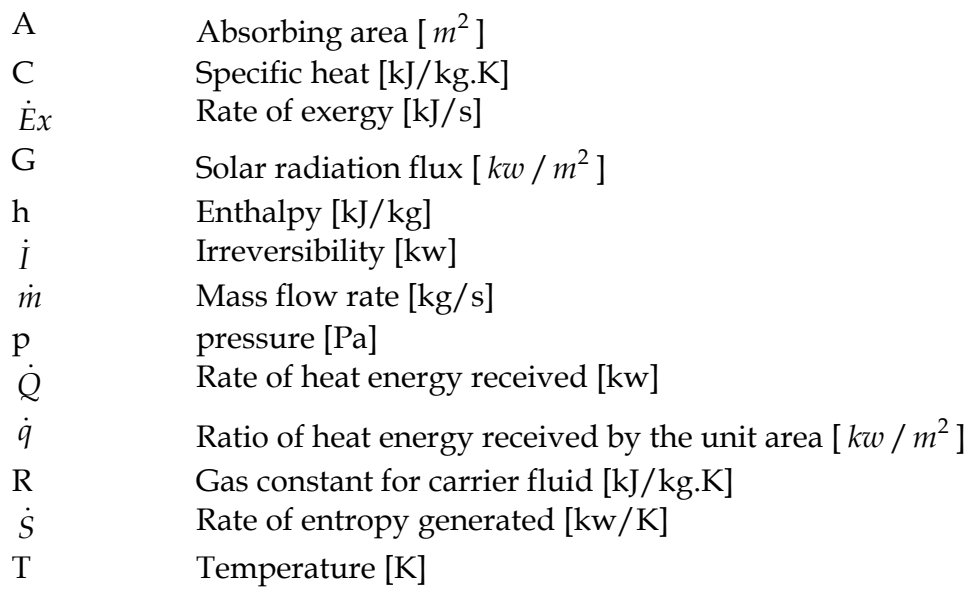

\section{Greek Letters}

$\eta \quad$ Efficiency (dimensionless)

$\tau \alpha \quad$ Absorbance-transmittance product (dimensionless)

$\Delta \quad$ Error in measuring or calculation

\section{Subscripts}

$\begin{array}{ll}\text { a } & \text { Ambient } \\ \mathrm{f} & \text { Carrier fluid (air) } \\ \mathrm{c} & \text { convection } \\ \text { col } & \text { Collector } \\ \mathrm{g} & \text { Glass cover } \\ \mathrm{d} & \text { Daily } \\ \text { en } & \text { Energy } \\ \text { ex } & \text { Exergy } \\ \text { gen } & \text { Generated } \\ \text { heat } & \text { Heat energy } \\ \text { hourly } & \text { Hourly } \\ \text { i } & \text { Inlet flow of carrier fluid } \\ \text { o } & \text { Outlet flow of carrier fluid } \\ \text { p } & \text { Absorber plate } \\ \text { s } & \text { Sun } \\ \text { work } & \text { Work }\end{array}$

\section{References}

[1] E, Mohseni Languri, H. Taherian, R. Masoodi, J. Reisel, An exergy and energy study of a solar thermal air collector, Thermal Science, 2009; 13(1):205-216. 
[2] Rene Tchinda, A review of the mathematical models for predicting solar air heaters systems, Renewable and Sustainable Energy Reviews 13 (2009) 1734-1759.

[3] Perrot, Pierre, A to Z of Thermodynamics, Oxford University Press, Oxford, 1998.

[4] Rant, Z., Exergy, a new word for technical available work, Forschung auf dem Gebiete des Ingenieurwesens 22, (1956), pp. 36-37.

[5] Gibbs, J. W. ,A method of geometrical representation of thermodynamic properties of substances by means of surfaces: reprinted in Gibbs, Collected Works, ed. W. R. Longley and R. G. Van Name, Transactions of the Connecticut Academy of Arts and Sciences, 2, (1931), pp. 382-404

[6] Moran, M. J. and Shapiro, H. N., Fundamentals of Engineering Thermodynamics, 6th Edition, 2007.

[7] Van Wylen, G.J., Thermodynamics, Wiley, New York, 1991.

[8] Wark, J. K., Advanced Thermodynamics for Engineers, McGraw-Hill, New York, 1995.

[9] Bejan, A., Advanced Engineering Thermodynamics, 2nd Edition, Wiley, 1997.

[10] Saravan, M. Saravan, R and Renganarayanan, S. , Energy and Exergy Analysis of Counter flow Wet Cooling Towers, Thermal Science, 12, (2008), 2, pp. 69-78.

[11] Bejan, A., Kearney, D. W., and Kreith, F., Second Law Analysis and Synthesis of Solar Collector Systems, Journal of Solar Energy Engineering, 103, (1981), pp. 23-28.

[12] Bejan, A. , Entropy Generation Minimization, New York, CRC press, 1996.

[13] Londono-Hurtado, A. and Rivera-Alvarez, A., Maximization of Exergy Output From Volumetric Absorption Solar Collectors, Journal of Solar Energy Engineering , 125, (2003), 1, pp. 83-86.

[14] Luminosu, I and Fara, L., Thermodynamic analysis of an air solar collector, International Journal of Exergy, 2, (2005), 4, pp. 385-408.

[15] Altfeld, K,. Leiner, W., Fiebig, M., Second law optimization of flat-plate solar air heaters Part I: The concept of net exergy flow and the modeling of solar air heaters, Solar Energy 41, (1988), 2, pp. 127-132.

[16] Altfeld, K., Leiner, W., Fiebig, M., Second law optimization of flat-plate solar air heaters Part 2: Results of optimization and analysis of sensibility to variations of operating conditions, Solar Energy, 41, (1988),4 , pp. 309-317.

[17] Torres-Reyes, E., Navarrete-Gonzàlez, J. J., Zaleta-Aguilar, A., Cervantes-de Gortari, J. G., Optimal process of solar to thermal energy conversion and design of irreversible flat-plate solar collectors, Energy 28, (2003), pp. 99-113.

[18] Kurtbas, I., Durmuş, A., Efficiency and exergy analysis of a new solar air heater, Renewable Energy, 29, (2004), pp. 1489-1501.

[19] Choudhury C, Chauhan PM, Garg HP. Design curves for conventional solar air heaters. Renewable energy 1995;6(7):739-49.

[20] Ong KS. Thermal performance of solar air heaters: mathematical model and solution procedure. Solar Energy 1995;55(2):93-109.

[21] Hegazy AA. Thermohydraulic performance of heating solar collectors with variable width, flat absorber plates. Energy Conversion and Management 2000;41:1361-78.

[22] Al-Kamil MT, Al-Ghareeb AA. Effect of thermal radiation inside solar air heaters. Energy Conversion and Management 1997;38(14):1451-8.

[23] Garg HP, Datta G, Bhargava K. Some studies on the flow passage dimension for solar air testing collector. Energy Conversion and Management 1984;24(3):181-4. 
[24] Forson FK, Nazha MAA, et Rajakaruna H. Experimental and simulation studies on a single pass, double duct solar air heater. Energy Conversion and Management 2003;44:1209-27.

[25] Ho CD, Yeh HM, Wang RC. Heat-transfer enhancement in double-pass flatplate solar air heaters with recycle. Energy 2005;30:2796-817.

[26] Duffie J.A, Beckman W.A, Solar engineering of thermal processes, 2nd ed. New York, John Wiley, 1991. 


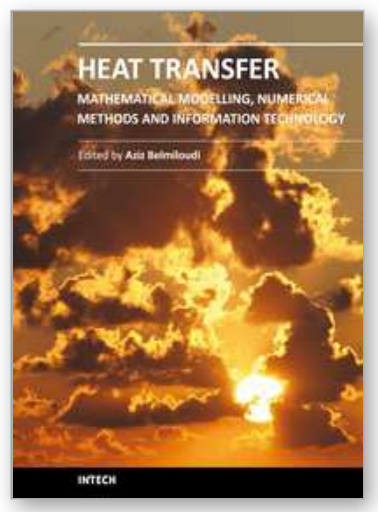

\section{Heat Transfer - Mathematical Modelling, Numerical Methods and Information Technology}

Edited by Prof. Aziz Belmiloudi

ISBN 978-953-307-550-1

Hard cover, 642 pages

Publisher InTech

Published online 14, February, 2011

Published in print edition February, 2011

Over the past few decades there has been a prolific increase in research and development in area of heat transfer, heat exchangers and their associated technologies. This book is a collection of current research in the above mentioned areas and describes modelling, numerical methods, simulation and information technology with modern ideas and methods to analyse and enhance heat transfer for single and multiphase systems. The topics considered include various basic concepts of heat transfer, the fundamental modes of heat transfer (namely conduction, convection and radiation), thermophysical properties, computational methodologies, control, stabilization and optimization problems, condensation, boiling and freezing, with many real-world problems and important modern applications. The book is divided in four sections : "Inverse, Stabilization and Optimization Problems", "Numerical Methods and Calculations", "Heat Transfer in Mini/Micro Systems", "Energy Transfer and Solid Materials", and each section discusses various issues, methods and applications in accordance with the subjects. The combination of fundamental approach with many important practical applications of current interest will make this book of interest to researchers, scientists, engineers and graduate students in many disciplines, who make use of mathematical modelling, inverse problems, implementation of recently developed numerical methods in this multidisciplinary field as well as to experimental and theoretical researchers in the field of heat and mass transfer.

\section{How to reference}

In order to correctly reference this scholarly work, feel free to copy and paste the following:

Ehsan Mohseni Languri and Davood Domiri Ganji (2011). Thermal Aspects of Solar Air Collector, Heat Transfer - Mathematical Modelling, Numerical Methods and Information Technology, Prof. Aziz Belmiloudi (Ed.), ISBN: 978-953-307-550-1, InTech, Available from: http://www.intechopen.com/books/heat-transfermathematical-modelling-numerical-methods-and-information-technology/thermal-aspects-of-solar-air-collector

\section{INTECH}

open science | open minds

\section{InTech Europe}

University Campus STeP Ri

Slavka Krautzeka 83/A

51000 Rijeka, Croatia

Phone: +385 (51) 770447

Fax: +385 (51) 686166

\section{InTech China}

Unit 405, Office Block, Hotel Equatorial Shanghai

No.65, Yan An Road (West), Shanghai, 200040, China 中国上海市延安西路65号上海国际贵都大饭店办公楼 405 单元

Phone: +86-21-62489820

Fax: +86-21-62489821 
www.intechopen.com 
(C) 2011 The Author(s). Licensee IntechOpen. This chapter is distributed under the terms of the Creative Commons Attribution-NonCommercialShareAlike-3.0 License, which permits use, distribution and reproduction for non-commercial purposes, provided the original is properly cited and derivative works building on this content are distributed under the same license. 